\title{
Introduction to the Special Series on Community Informatics
}

\author{
Eugene J. Rathswohl \\ University of San Diego, San Diego, CA, USA
}

gener@sandiego.edu

This special issue presents eight papers delivered originally at one of the two Informing Science conferences held in Krakow, Poland in 2001, and Cork, Ireland, in 2002. The eight papers cover several generic issues related to Community Informatics.

Community Informatics is the science and application of information and communication technologies (ICTs) to support human communities and their processes. A major concern of Community Informatics is how communities can utilize effectively ICTs in achieving their developmental, economic, social and cultural objectives. Much effort today in Community Informatics is finding ways of making the enormous opportunities of Internet connectivity of real value to communities of all types.

Community Informatics traditionally has been applied to local communities, which address the needs and interests of people in particular geographical areas. Briony Oates' paper, Foot and Mouth Disease: Informing the Community?, is an excellent case study of the variety of human needs, both shared and conflicting, that existed during the 2001 foot and mouth disease outbreak in the United Kingdom, and how ICTs were utilized both effectively and ineffectively by the community to cope with the crisis.

Community Informatics applies not only to local communities but also to virtual communities -- communities with no particular geographical limits. Virtual communities depend on information technology, but often are only using limited tool sets to support specific types of interaction and communications.

Betsy Van Dijk's paper, Navigation Assistance in Virtual Worlds, explores some of these issues and discusses research on forms of navigation assistance that enable non-professional visitors of a virtual environment to find their way without previous training, with implications for community development.

A major issue in Community Informatics is the effective and ethical use of systems development methodologies. Typically practitioners working to support communities are working with limited conceptualizations about the effective utilization of ICTs in community processes. Often they do not take full advantage of rapidly developing technology opportunities, and have little systematic contact with or feedback into on-going organizational or technology design, or emerging business models. These system design issues are discussed in the two papers by Chuck Winer and Thomas Pavkov, The Development of Consumer-Driven Human Services Information Technology Initiatives: The Lake County Indiana Experience and Human Services Information Technology, A Shared System. The authors present case stud-

Material published as part of this journal, either on-line or in print, is copyrighted by the publisher of Informing Science. Permission to make digital or paper copy of part or all of these works for personal or classroom use is granted without fee provided that the copies are not made or distributed for profit or commercial advantage AND that copies 1) bear this notice in full and 2) give the full citation on the first page. It is permissible to abstract these works so long as credit is given. To copy in all other cases or to republish or to post on a server or to redistribute to lists requires specific permission and payment of a fee. Contact Editor@inform.nu to request redistribution permission. ies illustrating the variety of value-laden issues in the analysis, design, and implementation of community information systems, especially the roles of researchers, practitioners, system developers, and community leaders and participants.

Regardless of the type of community - local or virtual - and the degree insightful use of systems development methods, Community Informatics must deal also with the human issues of the perceived usefulness or relevance of technology in

\section{Series Editors: Eugene Rathswohl and Charles Winer}


coping with community issues, especially gender related issues. Two papers discuss these issues. Kimberly Betz Leahy and Ira Yermish, in their paper Information and Communication Technology: Gender Issues in Developing Nations, present an analysis of women's lack of economic and educational parity in several developing countries and discuss how the education of women through the use of ICTs can enhance a nation's gross domestic product. Jo Rhodes, in her paper Can E-Commerce enable Marketing in an African Rural Women's Community Based Development Organization?, presents a case study of the Rural Women's Association of Sekhuhkuneland, Northern Province, South Africa showing how Internet technologies could enable access to economic markets by women entrepreneurs.

Another major Community Informatics issue is the level of conceptual and hands-on skills of the community members for utilizing effectively ICTs for their own needs. The papers by Nichole Fahey, The Importance of Addressing Accepted Training Needs When Designing Electronic Information Literacy Training, and Eugene Rathswohl, Information Literacy: A Community Service-Learning Approach, discuss a variety of educational issues relevant to designing and implementing literacy programs intended specifically to empower community members.

The eight papers presented in this special issue give a hint of the interdisciplinary nature of Community Informatics. Indeed, Community Informatics brings together researchers and practitioners from such varied disciplines as Sociology, Social Services, Planning, Computer Sciences, Information and Library Sciences, Management, Information Systems, among many others. In recent years several books dealing with Community Informatics have been published, many professional conferences have included Community Informatics sessions within the more generic title of Community and Society, and several Community Informatics web sites have been developed. You can use an Internet search engine to locate easily these various resources. A very useful listserve for promoting Community Informatics as an applied research discipline is CommunityInformatics@vcn.bc.ca hosted by Dr. Michael Gurstein of the Technical University of British Columbia. 